\title{
Theory of Planned Behavior: Determinants of the Use of Modern Family Planning Method
}

\author{
Yuliana Agus'), Eti Poncorini Pamungkasari²), RB. Soemanto3) \\ 1)Masters Program in Public Health, Universitas Sebelas Maret \\ 2)Faculty of Medicine, Universitas Sebelas Maret \\ 3)Faculty of Social and Political Sciences, Universitas Sebelas Maret
}

\begin{abstract}
Background: The use of contraception tool is one of the factors that affect fertility. It is influenced by demographic, socio-economic, legal, political and environmental factors. The use of modern family planning method can provide optimal benefits by minimizing side effects and complaints felt by the community. The aim is to analyze the determinants of the use of modern family planning method in Malinau District, North Kalimantan by using the theory of planned behavior.

Subjects and Method: This was an observational analytic study with cross sectional approach conducted in 4 (four) sub-districts in Malinau District, North Kalimantan, in December 2018 to January 2019. Total 200 subjects were selected by fixed disease sampling. The dependent variable was the mothers who applied the modern family planning method. The independent variables were maternal age, parity, area of residence, level of education, family income, perception, intention, attitude, and subjective norms. The data were collected by questionnaires and analyzed with path analysis.

Results: The use of modern family planning method in women is directly and positively influenced by parity $\geq 4(\mathrm{~b}=3.03 ; 95 \% \mathrm{CI}=1.23$ to $4.83 ; \mathrm{p}<0.001)$, high family income $(\mathrm{b}=4.57$; $95 \% \mathrm{CI}=2.66$ to $6.47 ; \mathrm{p}<0.001)$, positive attitude $(\mathrm{b}=3.92 ; 95 \% \mathrm{CI}=1.42$ to $6.42 ; \mathrm{p}=$ 0.002), and strong intention ( $\mathrm{b}=4.84 ; 95 \% \mathrm{CI}=2.85$ to $6.82 ; \mathrm{p}<0.001)$. The use of modern family planning method for women is indirectly influenced by the level of education and subjective norms.

Conclusions: The use of modern family planning method in women is directly and positively influenced by parity $\geq 4$, high family income, positive attitude, and strong intention. The use of modern family planning methods for women is indirectly influenced by the level of education and subjective norms.
\end{abstract}

Keywords: modern contraceptive methods, Theory of Planned Behavior

Correspondence:

Yuliana Agus. Masters Program In Public Health, Universitas Sebelas Maret, Jl. Ir. Sutami 36 A, Surakarta 57126, Central Java. Email: yulianaaguso7@gmail.com. Mobile: 085343928921

\section{BACKGROUND}

2014 World Population Data Sheet reported that Indonesia is a developing country ranking number 4 (four) having the largest population after China, India and the United States with a population of 261 million in 2017. In 2050, Indonesia will have up to 400 million people, so that it would undertake the position of the United States after
China and India (Haub and Kaneda, 2014). From 2013-2014 population growth, it increases by $1.5 \%$ from 3.65 million per year to 3.70 million per year. In 2017 population growth, it began to experience a decline from 2014 to 2.61 million per year. The use of contraception is one of the factors that affect fertility directly by being influenced by demographic, socio-economic, legal, po- 
litical and environmental factors. With the use of contraception, it is expected to reduce population growth very effectively.

The targets of the 2014-2019 National Medium Term Development Plan (RPJMN) is that BKKBN has to be responsible for achieving indicators of the Population, Family Planning and Family Development Program (KKBPK). Maternal health services include the use of modern family planning methods, which for the national figure increased from $55.8 \%$ (2010) to $59.7 \%$ (2013), with variations between provinces starting from the lowest in Papua (19.8\%) to the highest in Lampung (70.5\%). Of the $59.7 \%$ who use family planning, currently 59.3\% uses modern methods: $51.9 \%$ uses hormonal birth control, and 7.5\% uses nonhormonal methods. According to the method, $10.2 \%$ uses long-term contraception (MKJP) and $49.1 \%$ non-MKJP (Ministry of Health, 2018).

The family planning program can reduce the maternal mortality especially for women with $4 \mathrm{~T}$ conditions, namely too young to give birth (under the age of 20 years), too many children (children over 4), too close the distance of pregnancy or childbirth (pregnancy less than 2 years), and too old for childbirth (over 35 years old). The family planning program is expected to also be able to provide information services, education, and methods of contraceptive use for couples of childbearing age (PUS) that are more focused on women of childbearing age (WUS) around the age of 15-49 so that after getting counseling about contraception can determine contraceptive choices that are suitable for use with the conditions and needs based on information that has been received and understood, including the advantages and disadvantages of contraception (Ministry of Health, 2018). Indrawati's study (2015) found that there was a relationship between education level, knowledge, husband support, culture, level of welfare, communication, information, and education (KIE) KB with MKJP selection.

In 2016, the Department of Health, Population and Family Planning Control in Malinau District, North Kalimantan Province, reported that the total PUS in 2016 was 13,948 acceptors. Of 3,758 modern family planning participants, 1,938 were new participants and 1,815 active participants. In the Malinau Regency area of North Kalimantan Province, there were still many remote villages, so that it was difficult to access health care and information about family planning.

Data from literacy awareness rates in North Kalimantan in 2016 reached 84.13\%. According to gender composition, the literacy capacity of the female population is relatively lagging compared to the male population, which is around $91.87 \%$ compared to $85.67 \%$. The level of education is related to the ability to absorb and receive information including health information. Women who have higher education have wider knowledge and insight so that they are easier to absorb and receive information, and can play an active role in overcoming health problems for themselves and their families (North Kalimantan Health Office, 2016).

Based on the data above, the authors were interested in conducting study under the issue of Determinants of the Use of Modern Family Planning Methods in Malinau District, North Kalimantan using Theory of Planned Behavior.

\section{SUBJECTS AND METHOD}

\section{Study Design}

This was observational analytic study, with a cross sectional approach conducted in December 2018 to January 2019 in Malinau District, North Kalimantan. 


\section{Population and Sample}

The population in this study was all mothers who used the modern family planning method and the control population were all mothers who used modern non-family planning methods in 4 sub-districts in Malinau District, North Kalimantan. Total 200 subjects were selected by fixed disease sampling.

\section{Study Variables}

The dependent variable was the use of modern family planning method. The independent variables were maternal age, number of children (parity), area of residence, level of education, perception, intention, attitude, subjective norms, and family income.

\section{Operational Definitions of Study Variables}

Age was the age of the study subjects from birth to the time when the study was conducted. Parity was the number of children of the subjects, both born alive or dead. The area of residence was a place of family life and daily activities both socio-economic and cultural.

The level of education was the highest formal education status that has been taken through a structured and tiered educational path, assessed with the latest diploma. Perception was an action in compiling, recognizing, and interpreting information to provide an overview and understanding of the use of modern family planning methods. Intention was the desire or willingness of a mother to participate in an activity held.

Attitude was a person's conviction to behave whether the activity can be beneficial or not. Subjective norms were beliefs or the influence of family, friends, cadres, or health personnel on the behavior of someone in making a decision. Family income was the amount of income received by the nuclear family (husband, wife, or child who has worked) every month, both still want to be non-permanent. Modern family plan- ning was a contraceptive used to prevent pregnancy from using hormonal contraception, IUD, and steady contraception.

\section{Study Instruments}

The data was was collected by questionnaire in the form of checklists consisting of education levels, family income, modern family planning methods used, perceptions, attitudes, subjective norms, and intentions.

\section{Data Analysis}

The data analyzed by univariate analysis with sample characteristics, bivariate analysis with Chi-Square, and multivariate analysis with path analysis with STATA program 14. The data management was done using Path analysis through path specifications, model identification, structural models, parameter estimation, and model respecification.

\section{Research Ethics}

Research ethics that researchers pay attention to are informed consent, anonymity, confidentiality, and ethical clearance at the Research Ethics Commission of the Faculty of Medicine, Sebelas Maret University with numbers: 448 / UN27.06 / KEP / 2019.

\begin{tabular}{l}
\hline RESULTS \\
\hline 1. Univariate Analysis \\
Univariate analysis showed that the sam- \\
ples were less than 35 years amounting to \\
$61 \%$. Those whose parity were less than 3 \\
children were $51.5 \%$. Those who live in the \\
area of residence in both urban and rural \\
areas were $50 \%$. Those whose levels of edu- \\
cation were elementary and junior high \\
school graduates is $65.5 \%$. Those who have \\
high family income are $56 \%$. Those who \\
have negative perception were $53.5 \%$. Tho- \\
se who agree were $55 \%$. Those who had \\
subjective norms that affect were $54.5 \%$. \\
Those who had mother's intention were \\
$69.5 \%$. $50 \%$ of each type of modern family \\
planning has the same value.
\end{tabular}


Journal of Maternal and Child Health (2019), 4(5): 369-379

https://doi.org/10.26911/thejmch.2019.04.05.11

\section{Bivariate Analysis}

Bivariate analysis was performed using the analytical method with the Chi-Square test. Table 1 shows the factors that determine the use of modern FP methods are parity $\geq$ 4 children $(\mathrm{OR}=3.94 ; 95 \% \mathrm{CI}=1.23$ to 4.83; $\mathrm{p}<0.001$ ), high family income $\geq \mathrm{Mi}-$ nimum wage $(\mathrm{OR}=71.37 ; 95 \% \mathrm{CI}=2.66$ to
$6.47 ; \mathrm{p}<0.001)$, positive perceptions (OR = $3.32 ; 95 \% \mathrm{CI}=1.8$ to $5.9 ; \mathrm{p}<0.001$ ), agreeing attitudes $(\mathrm{OR}=17 ; 95 \% \mathrm{CI}=8.3$ to 34.6; $\mathrm{p}<0.001$ ), subjective norms ( $\mathrm{OR}=$ 7.11; CI 95\% = 3.7 to 13.3; $\mathrm{p}<0.001)$ and intention to want $(\mathrm{OR}=44.6 ; \mathrm{CI} 95 \%=1.32$ to $150.5 ; \mathrm{p}<0.001)$.

Table 1 The determinants of the Use of Modern Family Planning Methods

\begin{tabular}{|c|c|c|c|c|c|c|c|c|}
\hline \multirow[t]{2}{*}{ Variable } & \multirow[t]{2}{*}{ Category } & \multicolumn{2}{|c|}{$\begin{array}{c}\text { Non } \\
\text { Modern FP }\end{array}$} & \multicolumn{2}{|c|}{$\begin{array}{c}\text { Modern } \\
\text { FP }\end{array}$} & \multirow[t]{2}{*}{ OR } & \multirow[t]{2}{*}{ CI $95 \%$} & \multirow[t]{2}{*}{$\mathbf{P}$} \\
\hline & & $\mathbf{n}$ & $\%$ & $\mathbf{n}$ & $\%$ & & & \\
\hline \multirow[t]{2}{*}{ Age } & $\leq 35$ years & 66 & 54.1 & 56 & 45.9 & 1.52 & 0.8 to 2.7 & 0.192 \\
\hline & $>36$ years & 34 & 43.6 & 44 & 56.4 & & & \\
\hline \multirow[t]{2}{*}{ Parity } & $\leq 3$ children & 68 & 66 & 35 & 34 & 3.94 & 2.1 to 7.1 & $<0.001$ \\
\hline & $\geq 4$ children & 32 & 33 & 65 & 67 & & & \\
\hline \multirow{4}{*}{$\begin{array}{l}\text { Area of } \\
\text { residence } \\
\text { Level of } \\
\text { education }\end{array}$} & Rural area & 50 & 50 & 50 & 50 & 1.00 & 0.5 to 1.7 & 1.000 \\
\hline & Urban area & 50 & 50 & 50 & 50 & & & \\
\hline & PS and JHS & 59 & 45 & 72 & 55 & 0.56 & 0.3 to 1.0 & 0.074 \\
\hline & SHS and College & 41 & 59.4 & 28 & 40.6 & & & \\
\hline \multirow{2}{*}{$\begin{array}{l}\text { Family } \\
\text { income }\end{array}$} & Low & 82 & 93.2 & 6 & 6.8 & 71.37 & 27.0 to 188.3 & $<0.001$ \\
\hline & High & 18 & 16.1 & 94 & 83.9 & & & \\
\hline \multirow[t]{2}{*}{ Perception } & Negative & 68 & 63.6 & 39 & 36.4 & $3 \cdot 32$ & 1.8 to 5.9 & $<0.001$ \\
\hline & Positive & 32 & 34.4 & 61 & 65.6 & & & \\
\hline \multirow[t]{2}{*}{ Attitude } & Disagree & 75 & 83.3 & 15 & 16.7 & 17 & 8.3 to 34.6 & $<0.001$ \\
\hline & Agree & 25 & 22.7 & 85 & $77 \cdot 3$ & & & \\
\hline \multirow{4}{*}{$\begin{array}{l}\text { Subjektive } \\
\text { Norm } \\
\text { Intention }\end{array}$} & Does not affect & 68 & 74.7 & 23 & $25 \cdot 3$ & 7.11 & 3.7 to 13.3 & $<0.001$ \\
\hline & Affect & 32 & 29.4 & 77 & 70.6 & & & \\
\hline & No & 58 & 95.1 & 3 & 4.9 & 44.6 & 13.2 to 150.5 & $<0.001$ \\
\hline & Yes & 42 & 30.2 & 97 & 69.8 & & & \\
\hline
\end{tabular}

\section{Path Analysis}

Figure 1 shows the structural model of the variables. Table 2 shows the use of the modern family planning method that is directly influenced by parity $\geq 4$ children $(\mathrm{b}=$ 3.03; $95 \% \mathrm{CI}=1.23$ to $4.83 ; \mathrm{p} \leq 0.001$ ), high family income $\geq$ minimum wage $(\mathrm{b}=4.57$; $95 \% \mathrm{CI}=2.66$ to $6.47 ; \mathrm{p}<0.001)$, positive attitude $(\mathrm{b}=3.92$; CI $95 \%=1.42$ to 6.42 ; $\mathrm{p} \leq 0.002)$, and intention to want ( $\mathrm{b}=4.84$; CI $95 \%=2.85$ to $6.82 ; \mathrm{p}<0.001)$. Higher education level $(\mathrm{b}=2.39$; $95 \% \mathrm{CI}=1.73$ to 3.05; $\mathrm{p}<0.001)$ affects indirectly through high family income. Subjective norms influence indirectly through positive attitudes $(\mathrm{b}=1.10 ; 95 \% \mathrm{CI}=0.51$ to $1.69 ; \mathrm{p}$ $<0.001)$ and intention to want $(\mathrm{b}=1.46$; $95 \% \mathrm{CI}=0.81$ to $2.11 ; \mathrm{p}<0.001$ ). 


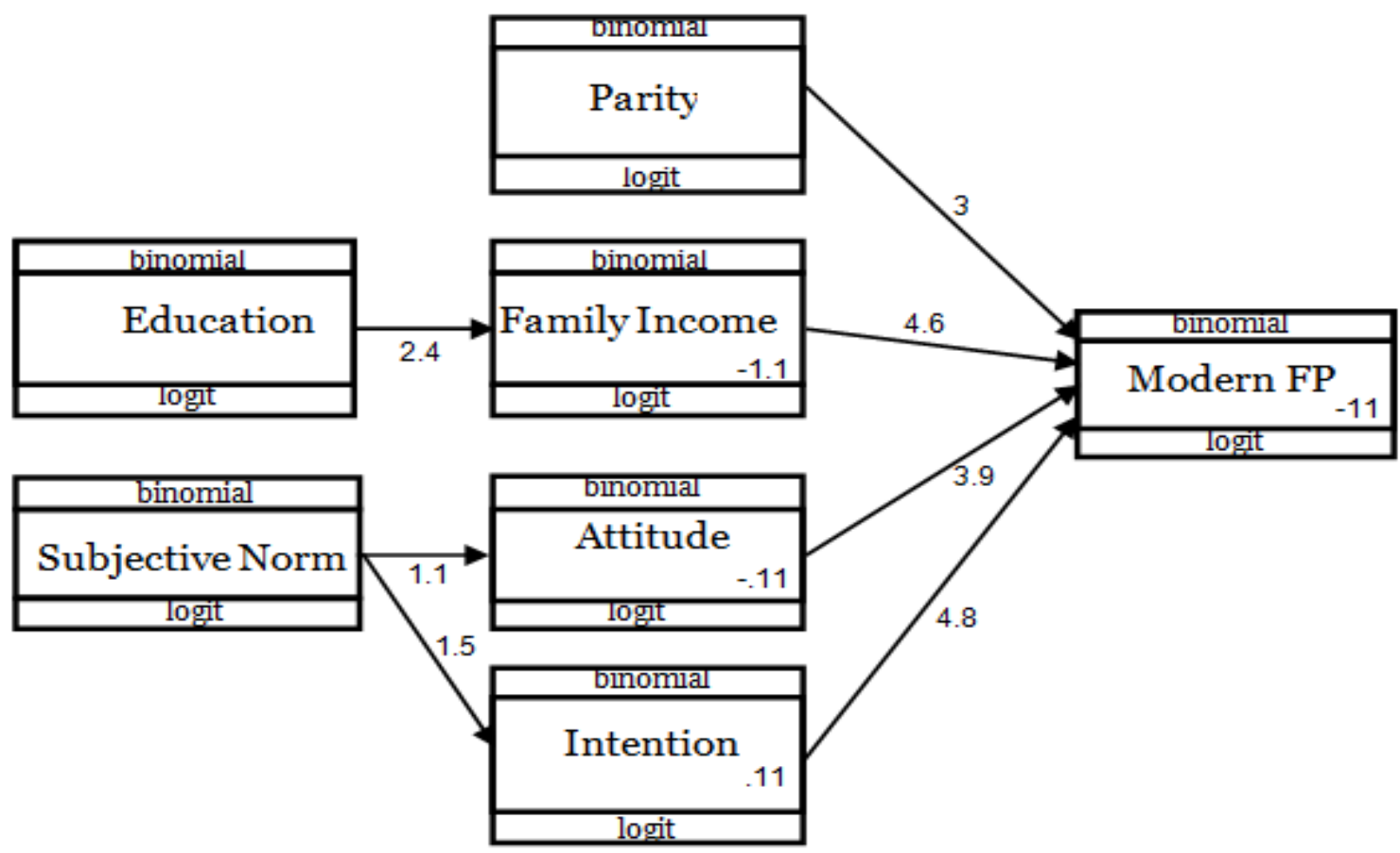

Figure 1 Structural Model of the Path Determinant Analysis of the Use of Modern Family Planning Method

Table 2 Path Analysis Results of the Use of Modern Contraceptive Methods Determinant

\begin{tabular}{llcccc}
\hline \multirow{2}{*}{$\begin{array}{l}\text { Dependent } \\
\text { Variable }\end{array}$} & \multirow{2}{*}{$\begin{array}{l}\text { Independent } \\
\text { Variable }\end{array}$} & $\begin{array}{c}\text { Path } \\
\text { Coefficient }\end{array}$ & $\begin{array}{c}\text { Lower } \\
\text { Limit }\end{array}$ & $\begin{array}{c}\text { Upper } \\
\text { Limit }\end{array}$ & \multirow{2}{*}{ p } \\
\cline { 1 - 1 } Direct Effect & & & & & \\
Modern FP & $\leftarrow$ Parity & 3.03 & 1.23 & 4.83 & 0.001 \\
& $\leftarrow$ Family Income & 4.57 & 2.66 & 6.47 & $<0.001$ \\
& $\leftarrow$ Attitude & 3.92 & 1.42 & 6.42 & 0.002 \\
Indirect Effect & $\leftarrow$ Intention & 4.84 & 2.85 & 6.82 & $<0.001$ \\
Family Income & $\leftarrow$ Education & & & & \\
Attitude & $\leftarrow$ Subjective Norm & 2.39 & 1.73 & 3.05 & $<0.001$ \\
Intention & $\leftarrow$ Subjective Norm & 1.10 & 0.51 & 1.69 & $<0.001$ \\
n Observation & $=200$ & & 0.81 & 2.11 & $<0.001$ \\
Log Likelihood & $=-377.18$ & & & & \\
\hline
\end{tabular}

\section{DISCUSSION}

1. The Effect of Parity on the Use of the Modern Family Planning Method

The results showed that there was a significant and direct effect of parity on the use of modern family planning methods in wo- men. Mothers with a parity of $\geq 4$ children increased logodd to use the modern family planning method by 3.03 units. This study showed that mothers with a number of parities $\geq 4$ children were more likely to use modern family planning methods compared to mothers who have parity $\leq 3$ children. 
The results of this study were similar to a study done by Mohammed et al. (2014) and Fitrianingsih (2018) which stated that parity influenced the use of modern family planning methods. In general, young mothers with a small number of children still did not have experience in the problem of choosing contraceptives that were well used compared to older mothers with $\geq 4$ children. A woman would have experience and knowledge about the types of contraception based on the number of children she has.

A study of Tsonga et al. (2014) stated that when choosing a contraception, couples of reproductive age would be influenced by the number of children they have. Couples of reproductive age who have a number of children were more likely to use non-modern family planning methods which have low effectiveness, whereas couples with a large number of children more likely to use modern birth control methods with high effectiveness. Families would begin to pay attention to the number of children because the number of children would be the responsibility of the head of the family in fulfilling the material needs and maintaining the health of the reproductive system because if the mothers gave birth for many times, their health would be more vulnerable and risky.

\section{The Effect of Family Income on the Use of the Modern Family Planning Method}

The results showed that there was a significant and direct effect between family incomes on the use of modern family planning methods. Mothers with high family income increased 4.57 points to use modern family planning methods. This study showed that mothers with high family income were more likely to use modern family planning methods compared to mothers with low family income.
The results of this study were similar to a study of Nonvignon (2014) and Putri et al. (2018) which stated that family income influenced the use of modern family planning methods. The income of a family was closely related to all needs in the family, including the need for health. Increasing family income to a higher level has an important role in increasing the use of modern family planning method (Mohammed et al., 2014 and Wijaya et al., 2016).

To overcome the problems experienced by low income families, since 1 April 2016 family planning services have been guaranteed by the Health Social Security Administration Agency (BPJS). In accordance with Presidential Regulation Number 82 Year 2018 concerning JKN, Article 48 paragraph 1 states that one the benefits of promotive and preventive services were the provision of family planning services, as referred to in paragraph 1 letter c covering counseling, contraceptive services including vasectomy and tubectomy, in collaboration with BKKBN (BKKBN, 2018 and Ningrum et al., 2017).

Although free family planning services for mothers of family income were low, not all health centers can fulfill all modern family planning services. So that mothers need to go to the city with expensive transportation costs, difficulties in getting transportation and there may are additional costs needed so that family income was very influential on the use of modern family planning methods (Health BPJS, 2016 and Ganle et al., 2014).

\section{The Effect of Attitude on the Use of the Modern Family Planning Me- thod}

The results showed that there was a significant and direct effect between maternal attitudes on the use of modern family planning methods. Mothers who agreed with modern family planning methods increased 
3.92 points to use modern family planning methods. This study showed that mothers who agree were more likely to use modern family planning methods compared to mothers who disagree with modern family planning methods.

The results of this study were similar to a study of Djauharoh (2015) and Saragih (2017) which stated that attitude affected the use of modern FP. Attitudes showed agreement or disagreement with something or like or dislike something. A good attitude towards something can be caused by positive trust and personal experience. And vice versa, if people have a negative belief in something, it would also cause a negative attitude. Attitudes would be easier to form if there was personal experience in situations that involve emotions, feelings, and appreciation of a deeper and more lasting experience, and the influence of other people who were considered important such as parents, peers, and people of high social status (Kurniati et al., 2017 and Setiasih et al., 2018).

\section{The Effect of Intention on the Use of the Modern Family Planning Method}

The results showed that there was a significant and direct effect between maternal intentions on the use of modern family planning methods. Mothers who have the intention to use one of the modern family planning methods increased 4.84 points to use the modern birth control method. This study showed that the mothers who have intention to use one of the modern family planning methods were more likely to use modern family planning methods compared to mothers who did not have the intention.

The results of this study were similar to a study of Joeliatin et al. (2017) and Triana et al. (2011) which stated that intention affected the use of modern FP. Inten- tion was assumed to be one of the motivational factors that can influence the behavior of how difficult people were willing to try new things as much as they try to do the behavior. According to the theory of planned behavior (TPB), intention was a cognitive representation of someone's readiness to perform certain behaviors or actions, and this intention can be used to measure a person's behavior or actions. If someone's intention was good, then the resulting action would be good and vice versa. This theory did not only focus on the ability to think logically from human behavior, but on behavioral beliefs or targets that were under the control of self-awareness so that they were not easily affected by others.

\section{The Effect of Educational Level on the Use of the Modern Family Plan- ning Method}

The results showed that there was an indirect and significant effect between the levels of education on the use of modern family planning methods through family income. Mothers with a high level of education were more likely to use modern family planning methods through family income.

The results of this study were similar to a study of Ezire et al. (2014) and Sinyal et al. (2019) which showed that there was an indirect effect between the level of education on the use of modern family planning methods through family income. Highlyeducated mothers have a loggod score of 2.39 points higher for using modern family planning methods through family income. This suggested that mothers with higher education can increase family income than those with low education.

The higher the level of education, the greater the opportunity to seek employment to earn income that was far greater than the value of MSEs. Education was one of the factors that allowed mothers to have economic independence by working outside the 
home, thereby helping to increase income and productivity in the family.

According to Lakew et al. (2013), the level of education greatly determined the pattern of family planning and the basic pattern of contraceptive use and improving family welfare. Families with high income and a high level of education have a higher awareness in efforts to maintain health and prevent illness. High education would make human life to be more qualified because high education would produce good knowledge so that life became more qualified. The level of someone's education would be influential in responding to something that came from outside and thinking rationally about the information that came to what extent the benefits would be obtained.

\section{The Effect of Subjective Norm on the Use of the Modern Family Planning Method}

The results showed that there was an indirect and significant effect between subjective norms on the use of modern family planning methods through maternal attitudes and intentions. Mothers with positive subjective norms can influence the use of modern family planning methods through maternal attitudes and intentions.

The results showed that subjective norms indirectly influence the use of modern family planning methods through the attitude of the mother. Mothers who agree with the modern family planning method have more than 1.10 points to use modern family planning methods compared to mothers who disagree.

The results of this study were in line with the study of Joeliatin et al. (2017) which stated that there was a relationship between subjective norms and maternal attitudes in using modern family planning methods. Subjective norms possessed by a mother have an important role in fostering a positive attitude about using modern family planning methods. Subjective norms also have a role as a function of belief that specifically someone agreed or disagreed to show a behavior.

Attitude was an evaluative response which would arise if the individual was faced with a stimulus that required an individual reaction. Positive attitudes towards modern family planning methods would be influenced by behavioral beliefs about the behavioral results that were raised, which occurred from the operation process, effectiveness, benefits and risks when using modern family planning methods, and outcomes evaluation would also be positive.

The results showed that subjective norms indirectly influence the use of modern family planning methods through maternal intentions. Mothers who have intention to use the modern family planning method were more than 1.46 points compared to mothers who did not have intention to use modern family planning methods. The results of this study were in line with study of Putri (2018) which stated that there was a relationship between subjective norms and women's intention to use modern family planning methods. Support from husbands who were included in subjective norms can have a positive impact on the awareness between partners for the importance of participating in family planning programs with modern family planning methods.

A study of Wijaya et al. (2016) stated that mothers who have the intention and plan to use one of the modern contraceptives have a great opportunity to realize their intentions in participating. This strong or weak intention was determined by the degree to which individuals have a positive attitude that was influenced by subjective norms. Intention would not be separated from the influence of self-consideration but from the consideration of other people who were 
considered important such as husbands or more experienced parents.

\section{AUTHOR CONTRIBUTION \\ Yuliana Agus formulated the study pro- blems, designs conceptual frameworks, col- lected data and processed data. Eti Ponco- rini as the giver of input in compiling words that are well used and the foundation theories in this study as well as giving ideas in discussing the results of study in the discussion. RB. Soemanto checked the results, discussion, and references.}

\section{FUNDING AND SPONSORSHIP}

This study used the authors' independent costs.

\section{ACKNOWLEDGEMENT}

The authors would like to express gratitude to authorities at 4 sub-districts in Malinau District, North Kalimantan, for assistance in data collection.

\section{CONFLICT OF INTEREST}

There is no conflict in this study.

\section{REFERENCE}

$\overline{\text { BKKBN (2018). Jurnal Keluarga: informasi }}$ kependudukan, keluarga berencana dan pembangunan keluarga. Jurnal Keluarga, 1(1), 44.

BPJS Kesehatan (2016). Ini strategi kepatuhan dan pemantapan layanan BPJS Kesehatan 2016. Info BPJS Kesehatan, (33), 12.

Djauharoh H (2015). Beberapa faktor yang berhubungan dengan penggunaan metoda kontrasepsi jangka panjang (studi pada akseptor KB di Kabupaten Sidoarjo Provinsi Jawa Timur ) Factors related to the use of long term contraception method (a study on contraceptive users in Kabu. 3(1).
Ezire O, Idogho O, Ajibade T, Ikani S, Oluigbo O (2014). Study on the patterns and trend in contraceptive use in South-South and North-Western zones of Nigeria: 2003\&ndash;2011. Open Access Journal of Contraception, 65. https://doi.org/10.2147/oajc.s49541

Fitrianingsih ADR, Melaniani S (2018). Faktor sosiodemografi yang memengaruhi pemilihan metode kontrasepsi. Jurnal Biometrika Dan Kependudukan, 5(1): 10. https://doi.org/10.20473/jbk.v5i1.2016.10-18

Ganle JK, Parker M, Fitzpatrick R, Otupiri $E$ (2014). Inequities in accessibility to and utilisation of maternal health services in Ghana after user-fee exemption: a descriptive study. International Journal for Equity in Health, 13(1). https://doi.org/10.1186/s12939-014oo89-z

Haub C, Kaneda T (2014). 2014 World population data sheet. Population Reference Bureau, August, 20. https://doi.org/Working Paper No. ESA/P/WP.241.

Health Office Malinau District (2016). Bidang Pelayanan kesehatan dan profil Puskesmas Dinas Kesehatan Kabupaten Malinau. Malinau: Dinas Kesehatan Kabupaten Malinau

North Kalimantan Health Office (2016). Profil Kesehatan Provinsi Kalimantan Utara. Tanjung Selor: Dinas Kesehatan Provinsi Kalimantan Utara

Indrawati LTNMF (2015). Analisis faktor yang berhubungan dengan pemilihan metode kontrasepsi jangka panjang (MKJP) pada akseptor KB Wanita di Kecamatan Banyubiru Kabupaten Semarang. Unnes Journal of Public Health, 2(2): 76-85.

Joeliatin, Murti B, Suryani N (2016). Theory of Planned Behavior on the Determinants of participation in the long- 
term contraceptive method among women of reproductive age, in Nganjuk, East Java. Journal of Health Promotion and Behavior, 1(3): 171-179. https://doi.org/10.26911/thejhpb.2016 .01 .03 .04

Kurniati A, Astirin OP, Suryani N (2017). Effect of maternal education, family income, mother-midwife interface, and the incidence of iron deficiency anemia in Pemalang, Central Java. Journal of Maternal and Child Health, 1(4): 220229. https://doi.org/10.26911/thejmch.2016.01.04.03

Lakew Y, Reda AA, Tamene H, Benedict S, Deribe K (2013). Geographical variation and factors influencing modern contraceptive use among married women in Ethiopia: evidence from a national population based survey. reproductive health, 10(1): 1. https://doi.org/10.1186/1742-4755-10-52

Mayi-Tsonga S, Obiang PA, Minkobame U, Ngouafo D, Ambounda N, De Souza $\mathrm{MH}$ (2014). Introduction of postabortion contraception, prioritizing long-acting reversible contraceptives, in the principal maternity hospital of Gabon. International Journal of Gynecology and Obstetrics. 126(1): 10-13. https://doi.org/10.1016/j.ijgo.2014.03.012.

Ministry of Health Republic of Indonesia (2018). Profil kesehatan Indonesia tahun 2017. Jakarta: Kementerian Kesehatan Republik Indonesia

Mohammed A, Woldeyohannes D, Feleke A, Megabiaw B (2014). Determinants of modern contraceptive utilization among married women of reproductive age group in North Shoa Zone, Amhara Region, Ethiopia. Reproductive Health, 11(1): 1-7. https://doi.org/10$.1186 / 1742-4755-11-13$

Ningrum SS, Indarto D, Wijaya M (2017).
Employment Status, family income, contraceptive availability, and their effects on the use of long term contraceptives in Sukoharjo, Central Java. Journal of Maternal and Child Health, 1(3): 179-187. https://doi.org/10.26911/thejmch.2016.01.03.05

Nonvignon J, Novignon J (2014). Trend and determinants of contraceptive use among women of reproductive age in Ghana. Etude de La Population Africaine, 28(2): 956-967.

Putri AP (2018). Program Studi D3 Keperawatan STIKES Mamba'ul 'Ulum Surakarta. Jurnal Terpadu Ilmu Kesehatan, 7(1): 6-14.

Putri VY, Ahmad LOAI, Lisnawaty (2018). Studi Psikografis dalam pemilihan alat kontrasepsi pada masyarakat suku baji di Desa Bajo Indah Kecamatan Soropia Kabupaten Konawe Tahun 2017. Jurnal Ilmiah Mahasiswa Kesehatan Masyarakat, 3(1): 1-8.

Saragih HR (2017). Metode Kontrasepsi jangka panjang pada istri pasangan usia subur (PUS) di Puskesmas Pancur Batu Kabupaten Deli Serdang Tahun 2017. Jurnal Ilmiah Pannmed, 12(3): 273-280.

Setiasih S, Widjanarko B, Istiarti T (2018). Analisis Faktor-faktor yang mempengaruhi pemilihan metode kontrasepsi jangka panjang (MKIP) pada wanita pasangan usia subur (PUS) di Kabupaten Kendal tahun 2013. Jurnal Promosi Kesehatan Indonesia, 11(2): 32. https://doi.org/10.14710/jpki.11.2.3246.

Sinyal MP, Rompas S, Bataha Y (2019). Di Rumah Sakit Manado Medical Center periode Juli-Desember 2018. E-Journal Keperawatan. 7(1): 1-7.

Triana V, Wilopo SA, Sumarni (2011). Pada wanita unmet need kontrasepsi di Indonesia (Analisis data SDKI 2007). 
Agus et al./ Theory of Planned Behavior: Determinants of the Use

Jurnal Kesehatan Masyarakat. 6(1): 28-35.

Wijaya VF, Rahardjo SS, Adriani RB (2016). Religious belief, social support, and the acceptance of intrauterine de- vice among women of reproductive age in Klaten, Central Java. Journal of Maternal and Child Health. 4(3): 201-211. https://doi.org/10.26911/thejmch.201 9.04.03.07. 